\title{
Qualification of Labour Safety Criminal Violations at Russian Coal Mining Enterprises
}

\author{
Marina Agienko ${ }^{1, *}$, Alexandr Naumov ${ }^{1}$, Irina Gaag $^{1}$, and Yuriy Volgin, ${ }^{1}$ \\ ${ }^{1}$ Plekhanov Russian University of Economics, Kemerovo Institute (Branch), 650992, Kuznetsky Av. \\ 39, Kemerovo, Russia
}

\begin{abstract}
In this paper, the issues of qualification of criminal safety violations at coal mining enterprises are discussed in detail. Firstly, a number of articles of the Criminal Code of the Russian Federation for qualification of these acts are defined. The differences between articles 143 and 216 of the Criminal Code of the Russian Federation with the analysis of a concrete example from judicial practice are considered. A similar procedure is carried out in the course of qualifying safety violations at coal mining enterprises under article 217 of the Criminal Code. In this work, the authors do not try to justify the need to decriminalize any articles of the Criminal Code of the Russian Federation, but try to work with the existing legislative framework so that the qualification rules formulated in the work can be used in practice. Also the authors formulate rules for the qualifications of the violations considered in this paper and propose amendments to the Criminal Code that do not require any "revolutionary" changes. A special difficulty is that there are no scientific recommendations on the qualification of criminal safety violations at coal mining enterprises.
\end{abstract}

\section{Introduction}

In the territory of the Kemerovo region (Kuzbass) there is a large number of coal-mining enterprises, and safety violations in any of them can lead to catastrophic consequences with a large number of human losses [1]. Unfortunately, there is not a single scientific work devoted to the analysis of the qualification of safety violations at coal mining enterprises under Russian law. That is why we consider it expedient to devote our study to this problem.

First of all, it is worth remembering that the concept of "qualification of crimes" is not fixed in any normative legal act, therefore, to understand this concept it is necessary to turn to scientific literature. Classical concept of the qualification of crimes explained it as the establishment and legal securing of an exact correspondence between the signs of the committed act and the signs of the composition of the crime provided for by the criminal law norm. In general, the concept of the qualification of crimes in the science of criminal law is considered settled, so we agree with this definition.

\footnotetext{
${ }^{*}$ Corresponding author: marinaivanovnaag@mail.ru
} 
The only source of criminal law in Russia is the Criminal Code of the Russian Federation. However, there is not a single article devoted to coal mining enterprises and (or) the process of coal mining or processing. This is precisely the difficulty in qualifying criminal violations of safety and security rules at coal mining enterprises - one should not simply establish the fact of such a violation, but also select the necessary article of the Criminal Code of the Russian Federation.

\section{Materials and methods}

The main normative legal act regulating coal mining is the Federal Law of 20.06.1996 No. 81-FZ "On state regulation in the field of coal mining and use, on the specifics of social protection of employees of coal industry organizations". Based on the meaning of article 13 of this Federal Law, coal mining is classified as mining. So, in accordance with article 1 of this Federal Law, mining works - a set of works (production processes) for the holding, fastening, maintenance of mine workings and extraction of minerals [2]. Since the fact that coal is a useful mineral is generally known, it is obvious that the law recognizes coal mining as mining work.

The Criminal Code of the Russian Federation provides for a provision that establishes liability for safety violations when conducting mountain, construction and other works article 216 of the Criminal Code. However, the specificity of article 216 of the Criminal Code of the Russian Federation is in its similarity with article 143 of the Criminal Code of the Russian Federation ("Violation of labor protection requirements") that is why it's necessary to distinguish it from article 216 of the Criminal Code in each case. Thus, the laws of the Russian Federation offer us a choice of two articles of the Criminal Code of the Russian Federation establishing liability for safety violations at coal mining enterprises.

In addition to Russian legislation, we analyzed the case law of general courts on the issue of safety violations at coal mining enterprises in recent years. We could find 60 sentences qualifying safety violations coal mining enterprises under article 216 of the Criminal Code of the Russian Federation, and only one - under article 143 of the Criminal Code. Thus, the courts clearly favor the qualification of the acts we are considering under article 216 of the Criminal Code. Besides, it was in 4 sentences that the safety violations at coal mining enterprises were qualified under article 217 of the Criminal Code ("Violation of safety rules in explosive areas").

Before consideration of the verdicts themselves, it is necessary to briefly consider the distinction between the constituent elements of offence of articles 143 and 216 of the Criminal Code. The differences in these elements have already been analyzed by A. Naumov:

- the differences in type of works performed: for qualification under article 216 of the Criminal Code of the Russian Federation it is necessary that the type of work involves a danger for a wide range of persons, at the same, time for qualification under article 143 of the Criminal Code of the Russian Federation the type of work does not matter;

- the differences of qualifying an injured victim: under article 143, if there is a violation of labor protection requirements, only the employee participating in the production of the works can be a victim, and any person may become a victim as a result of safety violations while conducting mining, construction and other works under article 216 ;

- the differences in the subject of the crime: the subject of the crime provided for in article 216 of the Criminal Code of the Russian Federation is any employee, and the subject of the crime provided for in article 143 of the Criminal Code of the Russian Federation is a person who is responsible for the observance the rules of labor protection. It is important to note that clause 3 of the Resolution of the Plenum of the Supreme Court of the Russian Federation of April 23, 1991 No. 1 lists such bodies. They are: firstly, persons who, by 
virtue of their official position or under a special order, are directly responsible for ensuring following the rules and norms of labor protection in a certain area of work; secondly, heads of enterprises and organizations, their deputies, chief engineers, chief specialists of enterprises. The last category is subject to liability under article 143 of the Criminal Code only under one of the following conditions: they did not take measures to eliminate a known violation of the rules of labor protection or issued instructions, contrary to these rules, or, having taken direct responsibility for certain types of work, did not ensure the following the rules mentioned [3].

- the differences of the nature of the violated rules: according to this criterion, there is no consensus in the literature. At first glance, this problem is purely speculative, since the previous criteria should be sufficient. However, based upon the position of the Supreme Court of the Russian Federation, the nature of the violated rules must be proved in each case, since in accordance with paragraph 3 clause 3 of the Resolution of the Plenum of the Armed Forces of the Russian Federation of 23.04.1991 No. 1 if a violation of rules and norms of labor protection is committed by an employee who was not a person specified in article 143 of the Criminal Code of the Russian Federation, and entailed the consequences listed in this article, the offense must be regarded as a crime against the person, regardless of whether the victim has relation to this production or not.

In clause 2 of the said Resolution Plenum of the Supreme Court of the Russian Federation is currently considering safety rules as one of the types of labor protection rules (requirements). And this cannot be regarded as negligence of the Supreme Court, because in the previous version of the Resolution of the Plenum the wording "... violation of the rules of labor protection and work safety ..." was used.

In the literature it is believed that in those industries, where special safety rules are established, general safety rules apply along with them, i.e. it is necessary to look at whether a particular rule is relevant only for this type of work (and then a qualification is required under article 216 of the Criminal Code of the Russian Federation) or for many types of work (then a qualification under article 143 of the Criminal Code is required), for example, non-providing with personal protective equipment, non-conduct of briefing/instruction, etc.

However, the literature rightly notes the impossibility of using this criterion in practice, because it is extremely difficult in reality to differentiate the rules (requirements) of occupational safety and safety regulations. The following fact makes it more complicated that in the article 216 of the Criminal Code of the Russian Federation the term "safety rules for the conduct of work" is used and not "safety rules".

The coal mining industry undoubtedly refers to the types of work associated with a danger for a wide range of people, therefore the criterion "type of work produced" inclines us to qualification under article 216 of the Criminal Code. However, no one has canceled the other criteria, and they also need to be guided.

Let us consider the sentence that qualifies the act we are considering under article 143 of the Criminal Code. "Electro mechanic Name1, having received a message from the mountain dispatcher about the failure of the generator on an excavator ECG-N ... on the pit of imported coal ... not having taken measures to control the supply of voltage to the workplace ..., allowed the work of the operator of the excavator Name6 and the assistant of the excavator operator Name 2 on dismantling of the generator for the excavator ECG-NN near the unprotected live parts ... Name6, performing the work on the dismantling of the generator, being unaware of ... the presence of high voltage on current-carrying parts, touched the unprotected live parts, as a result of which he was electrocuted at the scene ...

It is the actions of the defendant, who gave an oral instruction to carry out the dismantling of the generator to the machinist and the machinist assistant, thereby allowing them to do the specified work, did not carry out the required measures aimed at ensuring 
the safety of work, were the primary cause of the consequences that occurred as the victim's death. The whole work on the dismantling of the generator started and was carried out, as established in the court session, in the presence of the defendant, with his personal participation and at his disposal. Actions of Namel are in direct causal connection with the come consequences. Negligence of the victim, that took place in this case, is a subsequent factor arising from the actions of the defendant who allowed the victim to dismantle the generator" [4].

In the above case, the workers of the enterprise became victims. The guilty person belonged to the category of persons responsible for observing the rules of labor protection. As to the nature of the violated rules, the culprit violated several rules at once, some of which were of a general nature necessary for conducting any kind of work (e.g. lack of proper admission to work). In our opinion, the court's qualification in this case is correct.

The distinction between articles 216 and 217 of the Criminal Code of the Russian Federation (Violation of safety rules in explosive areas) is based on two criteria:

- the crime scene: for article 217 of the Criminal Code of the Russian Federation they are explosive objects or explosive workshops. Explosive object is a room or a section of terrain where explosive substances are located (gunpowder, TNT, pyrotechnic products, gasoline, kerosene, etc.) that have the ability to spontaneously explode under the influence of environmental factors (detonation, temperature increase, etc.). An explosive shop is one of the varieties of an explosive object. As to article 216 of the Criminal Code of the Russian Federation, the place where the crime was committed is not a constituent element of crime but the scenery/circumstances of the crime are obligatory: mine work, building and construction works and other types of work. It should be noted that for the coal mining industry this element does not matter - the coal mining industry, as we have already established, refers to mining activity, while coal mines and sections are explosive objects; - consequence: for article 216 of the Criminal Code of the Russian Federation the fact of serious negligence on health or cause major damage by negligence is obligatory (in the note to article 216 of the Criminal Code of the Russian Federation the minimum amount of major damage is 500,000 rubles). Article 217 of the Criminal Code also has two alternative consequences: the first - causing large-scale damage through negligence (coincides with article 216 of the Criminal Code of the Russian Federation), but the second consequence is completely different - the possibility of the death of a person. Thus if the constituent elements of crime according to article 216 of the Criminal Code is material, i.e. with mandatory consequences, according to article 217 of the Criminal Code consequences are not mandatory, only the threat of their occurrence is enough.

The sanctions of articles 216 and 217 of the Criminal Code of the Russian Federation are identical.

Let us turn to the verdicts that qualified the safety violations at coal mining enterprises under article 217 of the Criminal Code.

"Name1 received an order for the production of blasting at site No.15 OOO Voroshilov Mine ... did not deliver unspent explosives to the warehouse ... made unauthorized destruction of electric detonators left after the first cycle of blasting operations, having put a bunch of electric detonators on a shot coal, which was prohibited, realizing that in this way it allows safety violation occurrence on the explosive object, ... As a result of the actions of the shot-firer Name1 and the safety violation committed by him, the explosion of methane gas occurred at 14 hours 16 minutes and the mine overseer Name2, stope miner Name3, wiremen Name6, Name7 were injured and in case of emission of larger volume of gas into the stope and the achievement of explosive concentrations, an explosion could occur gas or gas and coal dust, what could lead to the death of people who were in the mining .... " [5].

In the given sentence death or serious harm to health was not caused to victims. 
Examples of sentences qualifying the acts we are considering under article 216 of the Criminal Code of the Russian Federation we will not give. Let us only note that in each sentence of this kind the convict is an ordinary worker (not related to the management of the enterprise), and there is at least one victim who suffered serious harm to his health or death.

\section{Results and discussion}

With 60 sentences with qualifications under article 216 of the Criminal Code, we have only one sentence with the qualifications of article 143 of the Criminal Code, despite the fact that prima facie case under article 143 of the Criminal Code is not uncommon. It seems that the reason for such "reluctance" of judges to qualify safety violations at coal mining enterprises under article 143 of the Criminal Code is in sanctions of the articles in question.

The maximum basic punishment for section 1 of article 143 of the Criminal Code (the act resulted by negligence in causing serious harm to human health) - imprisonment for up to one year, and the maximum basic punishment under section 1 of article 216 of the Criminal Code of the Russian Federation (the act resulted by negligence in causing serious harm to human health or major damage) - imprisonment for up to three years [2]. Similarly, sections 2 and 3 of article 216 of the Criminal Code provide for a heavier penalty than sections 2 and 3 of article 143 of the Criminal Code.

Thus, against the background of the enormous danger of violations in the coal mining industry, courts prefer to qualify under article 216 of the Criminal Code of the Russian Federation and inflict more severe punishment.

It seems that the situation in which article 216 of the Criminal Code is more severe than article 143 of the Criminal Code, is incorrect, because the subject of article 143 of the Criminal Code of the Russian Federation are not ordinary workers (who can be held responsible under article 216 of the Criminal Code), but only those responsible for compliance with labor protection rules (and, as we have already established, safety rules, in accordance with the position of the Supreme Court of the Russian Federation, are a particular case of labor protection rules).

Obviously, such persons are more powerful than ordinary workers, and therefore their negligence can cause much more serious consequences [6-8]. Therefore, we propose to tighten the sanction for committing crimes under article 143 of the Criminal Code, or at least equally toughen sanctions of articles 143 and 216 of the Criminal Code of the Russian Federation.

With regard to the considered verdict, as well as the verdicts on violations at coalmining enterprises under article 217 of the Criminal Code that have not been considered in this work, we can see the following pattern: in all these cases no victim was killed and in some of them there are no victims. Consequently, courts qualify safety violations at coal mining enterprises under article 217 of the Criminal Code of the Russian Federation only if no one was killed or seriously injured.

\section{Conclusions}

Safety violations at coal mining enterprises can be qualified according to articles 143, 216 and 217 of the Criminal Code of the Russian Federation. Based on the analysis of practice under article 143 of the Criminal Code of the Russian Federation, the acts in question must be qualified with the following factors: the victim is the employees of the enterprise; the subject of the crime is the person responsible for compliance with the requirements of labor protection by employees of the enterprise; presence among the violated rules of the 
"general rules of labor protection", like the lack of briefing, non-providing with personal protective equipment, for example, protective clothing etc. Cases with absence of consequences provided for by article 216 (if there was a threat of death, but no one was caused death or serious harm to health) should be qualified under article 217 of the Criminal Code. It is necessary to qualify other cases under article 216 of the Criminal Code.

To recommend to the legislator to amend the Criminal Code of the Russian Federation, toughening the amenability under article 143 of the Criminal Code of the Russian Federation, in order that, in its severity, article 143 of the Criminal Code equaled or surpassed article 216 of the Criminal Code.

\section{References}

1. M. I. Agienko, E. P. Bondareva, G. V. Chistyakova, O. V. Zhironkina, O. I. Kalinina, IOP Conf. Ser.: Mater. Sci. Eng., 142, 012022 (2016)

2. Federal Law of Russian Federation from 20.06.1996 No. 81-FZ "On state regulation in the field of coal mining and use, on the specifics of social protection of employees of coal industry organizations" (Law Office, Moscow, 1996)

3. V. G. Mikhailov, Ya. S. Mikhailova, Economics and Innovation Management, 3, 73-79 (2017) DOI: 10.26730/2587-5574-2017-3-73-79

4. The verdict of the Karpinsky City Court of the Sverdlovsk Region of March 19, 2012 No 10-3 (Law Office, Moscow, 1996)

5. The verdict of the Rudnichny District Court of the city of Prokopyevsk dated 19.09.2011 in case No. 1-377-11 (Law Office, Moscow, 1996)

6. S. Anyona, B.K. Rop, Economics and Innovation Management, 1, 17-29 (2017) DOI: 10.26730/2587-5574-2017-1-17-29

7. J. Janočko, M. Cehlár, Z. Šimková, Economics and Innovation Management, 3, 32-45 (2017) DOI: 10.26730/2587-5574-2017-3-32-45

8. Tyulenev, M., Zhironkin, S., Kolotov, K., Garina, E., Poll. Res. 35:2, 221-227 (2016) 